\title{
Estrogen-Induced Activation of the Mitogen-Activated Protein Kinase Cascade in the Cerebral Cortex of Estrogen Receptor- $\alpha$ Knock-Out Mice
}

\author{
Meharvan Singh, ${ }^{1}$ György Sétáló Jr, ${ }^{1,3}$ Xiaoping Guan, ${ }^{1}$ Donald E. Frail,, ${ }^{4}$ and C. Dominique Toran-Allerand ${ }^{1,2}$ \\ Departments of ${ }^{1}$ Anatomy and Cell Biology, and Centers for Neurobiology and Behavior and Reproductive Sciences, and \\ 2Neurology, Columbia University College of Physicians and Surgeons, New York, New York 10032, ${ }^{3}$ Department of \\ Biology, University Medical School of Pécs, Pécs H-7643, Hungary, and 4Womens Health Research Institute, Wyeth- \\ Ayerst Research, Radnor, Pennsylvania 19087
}

We have shown previously in the developing cerebral cortex that estrogen elicits the rapid and sustained activation of multiple signaling proteins within the mitogen-activated protein (MAP) kinase cascade, including B-Raf and extracellular signalregulated kinase (ERK). Using estrogen receptor (ER)- $\alpha$ genedisrupted (ERKO) mice, we addressed the role of ER- $\alpha$ in mediating this action of estrogen in the brain. $17 \beta$-Estradiol increased B-Raf activity and MEK (MAP kinase/ERK kinase)dependent ERK phosphorylation in cerebral cortical explants derived from both ERKO and their wild-type littermates. The ERK response was stronger in ERKO-derived cultures but, unlike that of wild-type cultures, was not blocked by the estrogen receptor antagonist $\mathrm{ICI} 182,780$. Surprisingly, both the ER- $\alpha$ selective ligand $16 \alpha$-iodo- $17 \beta$-estradiol and the ER- $\beta$ selective ligand genistein failed to elicit ERK phosphorylation, suggesting that a different mechanism or receptor may mediate estrogen-induced ERK phosphorylation in the cerebral cortex. Interestingly, the transcriptionally inactive stereoisomer $17 \alpha$ estradiol did elicit a strong induction of ERK phosphorylation, which, together with the inability of the ER- $\alpha$ - and ER- $\beta$ selective ligands to elicit ERK phosphorylation, and of $\mathrm{ICl}$ 182,780 to block the actions of estradiol in ERKO cultures, supports the hypothesis that a novel, estradiol-sensitive and $\mathrm{ICl}$-insensitive estrogen receptor may mediate $17 \beta$-estradiolinduced activation of ERK in the brain.

Key words: estradiol; estrogen receptor; ERK; ERKO; signal transduction; brain; cerebral cortex
The traditional view of estrogen action is that the estrogen receptor (ER) acts as a transcriptional modulator, requiring direct interaction with DNA. This mechanism, however, is neither sufficient to explain the rapidity of the effects of estrogen nor adequate to account for its wide range of actions in the brain, which include such responses as the enhancement of axon and dendrite (neurite) growth and differentiation (Toran-Allerand, 1976, 1984), neuroprotection (via multiple mechanisms) (Behl et al., 1995; Green et al., 1996; Simpkins et al., 1997), and influences on cognitive behaviors and functions (Singh et al., 1994; Luine et al., 1998). We have proposed an alternative hypothesis for estrogen action in the brain, involving interactions of the estrogen receptor system with various growth factors, including the neu-

Received Sept. 27, 1999; revised Nov. 30, 1999; accepted Dec. 13, 1999.

This work was supported in part by grants from National Institutes of Health (National Institute on Aging), National Institute of Mental Health, National Science Foundation, the Alzheimer's Association/Burks B. Lapham Grant, an Alzheimer's Association/T.L.L. Temple Foundation Discovery Award, the Bader Foundation, and an Alcohol, Drug Abuse, and Mental Health Administration Research Scientist Award, all to C.D.T.-A. We thank H.-J. Chung and M. F. Warren for their expert technical assistance. We also thank our colleagues at Columbia University: L. A. Greene for his technical advice and for providing valuable discussions, N. J. MacLusky for his valuable suggestions and critically reviewing our manuscript, and J. Angelastro and M. Cunningham for their technical advice. We also thank R. A. Rush (Flinders University, Adelaide, Australia) for the anti-rat blocking antibodies to BDNF and NT-3, A. E. Wakeling (Zeneca Pharmaceuticals, Macclesfield, Cheshire, UK) for the gift of ICI 182,780, R. B. Hochberg (Yale University, New Haven, CT) for the gift of $16 \alpha$-iodo $17 \beta$-estradiol, and the Bioresource staff at Wyeth-Ayerst for providing the ERKO animals.

Correspondence should be addressed to Dr. Dominique Toran-Allerand, Department of Anatomy and Cell Biology, 650 West 168th Street, BB 1615, New York, NY 10032. E-mail: cdt2@columbia.edu.

Copyright (C) 2000 Society for Neuroscience $\quad 0270-6474 / 00 / 201694-07 \$ 15.00 / 0$ rotrophins, a class of molecules also known to be important for the development and survival of neurons (Toran-Allerand, 1996). We demonstrated previously colocalization of the estrogen receptor with the neurotrophin ligands and their receptor systems (p75 ${ }^{\text {NTR }}$ and the trks) in neurons of the developing CNS (ToranAllerand et al., 1992; Miranda et al., 1993), providing an anatomical substrate and the potential for interactions of estrogen with the neurotrophins. In fact, not only has reciprocal regulation of these two receptor systems by their ligands been described previously (Sohrabji et al., 1994), but convergence, or cross-coupling, of their signal transduction pathways has also been documented in the developing cerebral cortex in which estradiol elicited the rapid and sustained activation of multiple members of the mitogen-activated protein (MAP) kinase cascade, including B-Raf and the extracellular signal-regulated kinases ERK1 and ERK2 (Singh et al., 1999). Through the intermediary of ERK activation, the very rapid effects of estrogen (Chiaia et al., 1983; Garcia-Segura et al., 1987; Migliaccio et al., 1993), as well as the influence of estrogen on genes that do not contain a canonical estrogen response element (ERE) (Sukovich et al., 1994), may be better explained.

With the recent cloning of a second estrogen receptor, ER- $\beta$ (in which the classical ER is now termed ER- $\alpha$ ), it became important to identify the estrogen receptor subtype that mediates estrogen activation of ERK. We studied the effects of $17 \beta$ estradiol on cerebral cortical explants derived from the ER- $\alpha$ gene-disrupted (ERKO) mouse (Lubahn et al., 1993) and show here that $17 \beta$-estradiol activates B-Raf and ERK in the cerebral cortex derived from both ERKO and their wild-type littermates, 
with the ERK response being stronger in ERKO-derived cultures. Moreover, neither the ER- $\alpha$-selective ligand $16 \alpha$-iodo- $17 \beta$ estradiol (Shughrue et al., 1999) nor the ER- $\beta$-selective ligand genistein (Witkowska et al., 1997) were capable of eliciting ERK phosphorylation. Together with the inability of the estrogen receptor antagonist ICI 182,780 to block this action of estradiol in ERKO tissue and the ability of the transcriptionally inactive stereoisomer $17 \alpha$-estradiol to elicit strong ERK phosphorylation, our data support the hypothesis that a novel, estradiol-sensitive and ICI-insensitive estrogen receptor may mediate the stimulatory effect of estradiol on ERK activation in the developing cerebral cortex.

\section{MATERIALS AND METHODS}

Mice. Six breeding pairs of C57BL/6J mice heterozygous for the ER- $\alpha$ gene disruption (Lubahn et al., 1993) were mated for each experiment.

Genotyping. On the day of birth [postnatal day 1 (P1)], tail snips were obtained from the pups and used for genotyping. Briefly, tissues were digested with Proteinase $\mathrm{K}$ at $56^{\circ} \mathrm{C}$ for $90 \mathrm{~min}$, followed by a $99^{\circ} \mathrm{C}$ incubation for $10 \mathrm{~min}$. The samples were then vortexed vigorously, and insoluble material was pelleted in a microfuge. Supernatants were used in a PCR reaction that used one primer pair (primer $1,5^{\prime}-\mathrm{CGG}$ TCT ACG GCC AGT CGG GCA TC-3'; primer 2, 5'-GTA GAA GGC GGG AGG GCC GGT GTC-3') for the ER- $\alpha$ gene product (product size of $239 \mathrm{bp}$ ) and one primer pair (primer 2 from above with NEO primer 5'-GCT GAC CGC TTC CTC GTG CTT TAC-3') for the neomycin insert-containing gene product (product size of $790 \mathrm{bp}$ ). The PCR program was performed as follows: 1 cycle at $94^{\circ} \mathrm{C}$ for $3 \mathrm{~min}$, and 30 cycles of $94^{\circ} \mathrm{C}$ for $45 \mathrm{sec}, 62^{\circ} \mathrm{C}$ for $1 \mathrm{~min}$, and $72^{\circ} \mathrm{C}$ for $1 \mathrm{~min} 40 \mathrm{sec}$, followed by a final extension cycle of $72^{\circ} \mathrm{C}$ for $7 \mathrm{~min}$. Products were analyzed by agarose gel electrophoresis. Wild-type animals revealed the smaller, 239 bp band, homozygous knock-outs showed the larger $790 \mathrm{bp}$ band, and heterozygotes displayed both bands.

Each breeding resulted in the generation of approximately six to eight homozygous ERKO pups, approximately the same number of wild-type animals, and almost double the number of heterozygotes. Pups homozygous for the ERKO and wild-type littermates, but not heterozygotes, were used to prepare cultures on P3.

Tissue culture. Hemicoronal slices (360 $\mu \mathrm{m}$ thick) of P3 frontal and cingulate cerebral cortex derived from either wild-type or ERKO pups were prepared and maintained by the roller tube culture technique in steroid-deficient and phenol red-free nutrient medium, supplemented with a cocktail of human recombinant neurotrophins (NGF, BDNF, NT-3, NT-4/5; $50 \mathrm{ng} / \mathrm{ml}$ each; Intergen, Purchase, NY) and 17 $\beta$-estradiol (2 nM; Sigma, St. Louis, MO), as described previously (Singh et al., 1999). Previous observations in our laboratory have established that the addition of estrogen and the neurotrophins to the nutrient media optimizes the development of the cultures (C. D. Toran-Allerand, unpublished observations).

Treatment of cultures. After $6 \mathrm{~d}$ in vitro, a $24 \mathrm{hr}$ washout period was performed, consisting of both omitting exogenously added $17 \beta$-estradiol and neurotrophins, and adding blocking antibodies to rodent NGF (Sigma), BDNF, and NT-3 [gift of R. A. Rush, Flinders University, Adelaide, Australia (Zhou and Rush, 1995)]. The following day, explants were pulsed with $10 \mathrm{~nm} 17 \beta$-estradiol or $100 \mathrm{ng} / \mathrm{ml}$ each individual neurotrophin (NGF, BDNF, NT-3, and NT-4/5) administered together as a cocktail for a single $30 \mathrm{~min}$ time point. The neurotrophin-treated cultures served as positive controls. For the evaluation of the effect of the transcriptionally inactive stereoisomer of $17 \beta$-estradiol, $17 \alpha$-estradiol, cultures were pulsed with $10 \mathrm{~nm} 17 \alpha$-estradiol for $0,15,30$, or $60 \mathrm{~min}$.

The individual contributions of ER- $\alpha$ and ER- $\beta$ to estrogen-induced ERK phosphorylation were evaluated using the selective ligands $16 \alpha$ iodo-17 $\beta$-estradiol and genistein, respectively. $16 \alpha$-Iodo- $17 \beta$-estradiol (Hochberg and Rosner, 1980) (gift of R. B. Hochberg, Yale University, New Haven, CT), which is selective for ER- $\alpha$ at concentrations below 10 nM (Shughrue et al., 1999), was administered for $30 \mathrm{~min}$ to the cerebral cortical explants. Genistein (Upstate Biotechnology, Lake Placid, NY), an ER- $\beta$-selective ligand (Witkowska et al., 1997), was also studied with respect to its ability to phosphorylate ERK. Displacement curves evaluating the displacement of ${ }^{3} \mathrm{H}$-estradiol from either the ER- $\alpha$ or ER- $\beta$ ligand binding domains have revealed that genistein binds preferentially to ER- $\beta$ in the low to mid nanomolar range (Witkowska et al., 1997). As such, genistein was administered to cerebral cortical explants for $30 \mathrm{~min}$ at concentrations of $0.1,1,10$, and $100 \mathrm{nM}$. However, in the presence of $10 \mathrm{~nm} 17 \beta$-estradiol, $100 \mu \mathrm{M}$ genistein, a concentration at which genistein acts as a tyrosine kinase inhibitor (Akiyama et al., 1987), served as a positive control, verifying the activity of the genistein used.

To identify the effect of the estrogen receptor antagonist ICI 182,780 (gift of A. E. Wakeling, Zeneca Pharmaceuticals, Macclesfield, Cheshire, UK) on $17 \beta$-estradiol-induced ERK phosphorylation, cultures were pretreated with either $1 \mu \mathrm{M}$ ICI 182,780 or $0.1 \%$ DMSO (vehicle control) 24 $\mathrm{hr}$ before pulsing the explants. After $24 \mathrm{hr}$, cultures were treated with 10 nM $17 \beta$-estradiol in the continued presence of either the antagonist or the vehicle control. For MEK (MAP kinase/ERK kinase) inhibition, the cultures were pretreated with either the MEK1/2 inhibitor PD98059 (100 $\mu \mathrm{M}$; New England Biolabs, Beverly, MA) or $0.1 \%$ DMSO for $4-5 \mathrm{hr}$ before pulsing the cultures with the appropriate $17 \beta$-estradiol or neurotrophin treatments.

Western blot analysis (ERK phosphorylation). Cultures were harvested into protease inhibitor- and phosphatase inhibitor-containing lysis buffer and prepared for PAGE, as described previously (Singh et al., 1999). After electrophoretic separation, proteins were transferred onto polyvinylidene difluoride membranes $(0.22 \mu \mathrm{m}$ pore size; Bio-Rad, Hercules, CA), blocked overnight with $3 \%$ BSA (Fraction V; Sigma) in Trisbuffered saline containing $0.2 \%$ Tween-20, and probed with the following antibodies: for ERK phosphorylation, rabbit anti-phosphoMAPK (dual phospho-specific (Thr202/Tyr204), 1:1000; New England Biolabs); for ERK protein determination, goat or rabbit anti-ERK1 (1:1000), or goat or rabbit anti-ERK2 (1:1000; Santa Cruz Biotechnology, Santa Cruz, CA). Antibody binding to the membrane was detected using a secondary antibody (either goat anti-rabbit or donkey anti-goat) conjugated to horseradish peroxidase (1:40,000; Pierce, Rockford, IL) and visualized on autoradiographic film using enzyme-linked chemiluminescence (Amersham, Arlington Heights, IL). All blots depicting phosphoERK levels were reprobed with the anti-ERK1 and ERK2 antibodies to verify equal loading of protein across lanes, and where necessary, densitometric analysis of the ERK protein levels were performed to ensure similar levels of protein loaded across lanes.

$B$-Raf kinase assay. Cerebral cortical explants were lysed and incubated with a rabbit anti-B-Raf antibody (Santa Cruz Biotechnology) for $3 \mathrm{hr}$ and precipitated using anti-rabbit IgG-coated magnetic beads (Dynabeads; Dynal, Oslo, Norway). As a negative control, a preimmune IgG-immunoprecipitated cortical lysate was always run in parallel with the experimental samples. After four washes with lysis buffer, the B-Rafbound beads were used as the starting material for the B-Raf kinase assay. The assay procedure was performed according to the protocol provided in the B-Raf kinase assay kit (Upstate Biotechnology) and is based on the phosphorylation of myelin basic protein (MBP) by a B-Raf-activated kinase cascade using radioactive ATP as the final phosphate donor. Briefly, assay dilution buffer [20 mM 3-( $N$-morpholino) propane sulfonic acid (MOPS), $\mathrm{pH} 7.2,25 \mathrm{~mm} \beta$-glycerol phosphate, 5 mM EGTA, $1 \mathrm{~mm} \mathrm{Na}_{3} \mathrm{VO}_{4}$, and $1 \mathrm{~mm}$ dithiothreitol] and the magnesiumcold ATP cocktail were added in conjunction with $0.4 \mu \mathrm{g}$ of inactive MEK1 and $1 \mu \mathrm{g}$ of inactive glutathione $S$-transferase-p42 MAP kinase. This mixture was then incubated for $30 \mathrm{~min}$ at $30^{\circ} \mathrm{C}$. Additional assay dilution buffer, MBP, and $\left[\gamma_{-}{ }^{32} \mathrm{P}\right]$ ATP were added subsequently and incubated for another $10 \mathrm{~min}$ at $30^{\circ} \mathrm{C}$ while shaking thoroughly. After boiling the samples for $5 \mathrm{~min}, 25 \mu \mathrm{l}$ of the supernatant was spotted onto P81 phosphocellulose paper, which exhibits differential binding of the phosphorylated MBP from unincorporated ${ }^{32} \mathrm{P}$. Radioactivity incorporated into the P81 paper was then counted using a scintillation counter (Searle model Delta 300).

Statistical analysis. Resulting counts per minute values obtained from the B-Raf kinase assay were analyzed using a one-way ANOVA, followed by Scheffe's post hoc analysis for group differences. Statistical analyses were performed using the SPSS software (SPSS Inc., Chicago, IL).

Densitometric analyses. Autoradiograms were scanned using an HP Scanjet 6200C (Hewlett Packard Company, Greeley, CO) and analyzed using Kodak 1D Image Analysis software (Eastman Kodak, Rochester, NY). Net intensity values were calculated by subtracting the background within the area measured for each band, from the total intensity within this same measured area to account for any variation in background intensity across the film.

\section{RESULTS}

A single 30 min treatment of $17 \beta$-estradiol, a time point shown previously to elicit significant ERK1 and ERK2 phosphorylation 

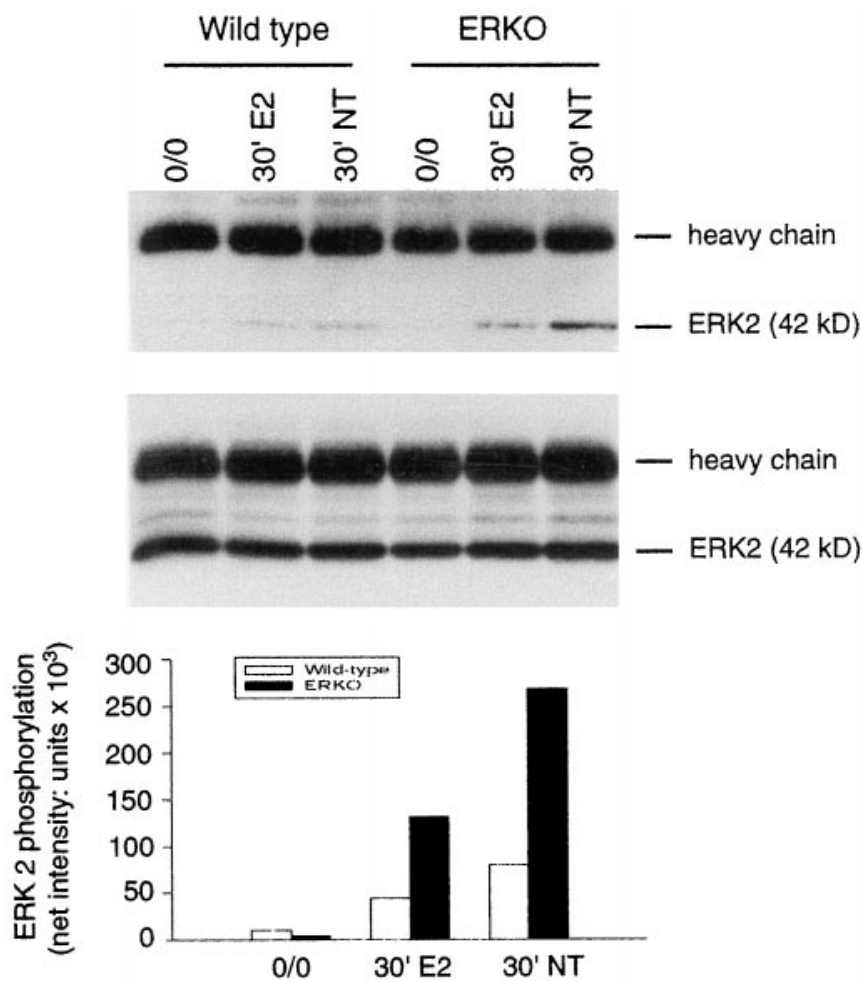

Figure 1. $17 \beta$-Estradiol-induced ERK phosphorylation in wild-type and ERKO cerebral cortex. Cerebral cortical explants derived from either wild-type or ERKO mice were treated for a single $30 \mathrm{~min}$ time period with either $10 \mathrm{~nm} 17 \beta$-estradiol or a neurotrophin cocktail (of NGF, BDNF, NT-3, and NT-4/5 at $100 \mathrm{ng} / \mathrm{ml}$ each). Cortical lysates were immunoprecipitated for ERK protein and subsequently probed for phosphotyrosine using the $4 \mathrm{G} 10$ anti-phosphotyrosine antibody (Upstate Biotechnologies). ERK phosphorylation was seen both in wild-type and ERKO cultures, although the extent of phosphorylation was stronger in ERKO cultures. The bottom panel represents reprobing of the phosphotyrosine blot for ERK protein to verify equal loading of protein across lanes. Densitometric representation of the relative intensities of ERK phosphorylation is also provided, revealing the significant enhancement of $17 \beta$-estradiol-induced ERK phosphorylation in ERKO cultures. Data shown are representative of three independent experiments.

and activation (Singh et al., 1999), was administered to cerebral cortical explants derived from ERKO and wild-type mice. Whereas $17 \beta$-estradiol elicited ERK phosphorylation in both ERKO and wild-type cerebral cortex (Fig. 1), ERKO cultures showed a more robust response. ERK phosphorylation levels in ERKO tissue were increased 29 -fold in response to $17 \beta$-estradiol, whereas wild-type cultures exhibited only a fourfold increase. Interestingly, the effect of the neurotrophins was also augmented in ERKO tissue.

To further evaluate the individual contributions of ER- $\alpha$ and ER- $\beta$ on ERK phosphorylation in wild-type cultures, we analyzed the effects of the halogenated estrogen $16 \alpha$-iodo- $17 \beta$ estradiol (Hochberg and Rosner, 1980), which has a selective affinity for mouse ER- $\alpha$ at concentrations below $10 \mathrm{~nm}$ (Shughrue et al., 1999), and of the phytoestrogen genistein, which has a selective affinity for ER- $\beta$ (Witkowska et al., 1997). $16 \alpha$-Iodo$17 \beta$-estradiol at concentrations of $0.1,1$, and $10 \mathrm{~nm}$ not only failed to elicit ERK phosphorylation but actually resulted in an $\sim 70 \%$ reduction of baseline ERK phosphorylation (Fig. 2). The effect of the ER- $\beta$-selective ligand genistein (Witkowska et al., 1997) was also evaluated and found to be without influence on ERK phos-
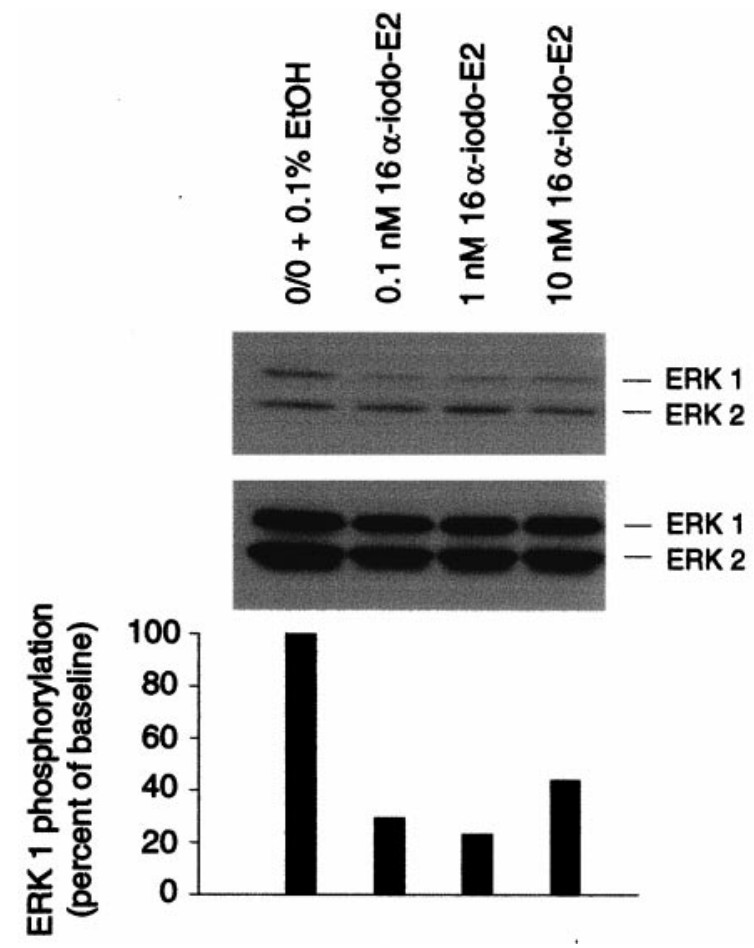

Figure 2. Effect of $16 \alpha$-iodo- $17 \beta$-estradiol on ERK phosphorylation in wild-type cerebral cortex. The ER- $\alpha$-selective ligand $16 \alpha$-iodo- $17 \beta$ estradiol was evaluated for its ability to phosphorylate ERK [using the dual phospho-specific ERK antibody (New England Biolabs)]. At concentrations known to selectively bind ER- $\alpha$, this ligand failed to elicit ERK phosphorylation. The bottom panel represents reprobing of the phosphoERK blot for ERK protein to verify equal loading of protein across lanes. Densitometric representation of the relative intensities of ERK1 phosphorylation is also provided, demonstrating significant inhibition of ERK1 phosphorylation in response to $16 \alpha$-iodo- $17 \beta$-estradiol. Data are representative of three independent experiments.

phorylation at concentrations ranging from 0.1 to $100 \mathrm{~nm}$ (Fig. 3). However, at $100 \mu \mathrm{M}$, a concentration at which genistein acts as a tyrosine kinase inhibitor (Akiyama et al., 1987), 17 $\beta$-estradiolinduced ERK phosphorylation was successfully inhibited, verifying that the genistein used was indeed biologically active. Because both $16 \alpha$-iodo- $17 \beta$-estradiol and $17 \beta$-estradiol have similar affinities for ER- $\alpha$ (Hochberg and Rosner, 1980), the inability of $16 \alpha$-iodo-17 $\beta$-estradiol to stimulate ERK phosphorylation is probably not attributable to inadequate binding to the estrogen receptor, particularly because a concentration as low as $0.1 \mathrm{~nm}$ $17 \beta$-estradiol was sufficient to activate ERK (data not shown). Interestingly, the transcriptionally inactive stereoisomer for $17 \beta$ estradiol, $17 \alpha$-estradiol, was equally capable of eliciting phosphorylation of ERK (Fig. 4).

The ability of the estrogen receptor antagonist ICI 182,780 to inhibit $17 \beta$-estradiol induction of ERK phosphorylation was also evaluated in the cerebral cortex derived from both genotypes. ICI 182,780 blocked the effect of $17 \beta$-estradiol on ERK phosphorylation in wild-type cortical cultures (Fig. $5 A$ ) but not in those derived from ERKO mice (Fig. $5 B$ ). Neurotrophin induction of cortical ERK phosphorylation was unaffected by the ICI compound. The MEK1/2 inhibitor (PD98059), on the other hand, inhibited $17 \beta$-estradiol- and neurotrophin-induced ERK phosphorylation in both wild-type and ERKO cultures (Fig. 6).

To determine whether the activation of elements upstream of ERK was still possible after the disruption of cortical ER- $\alpha$ 

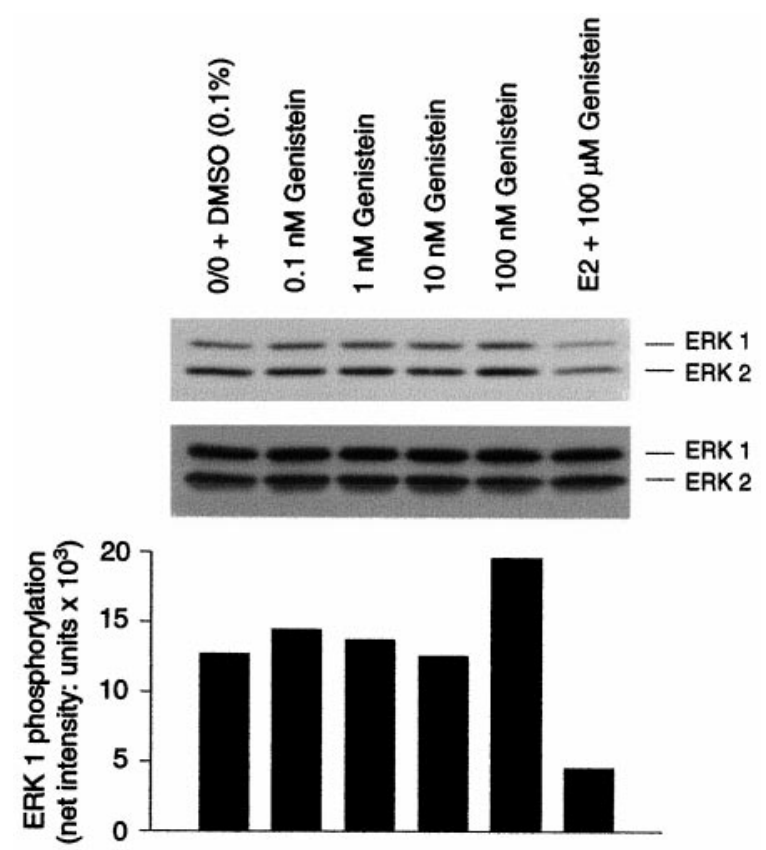

Figure 3. The effect of genistein on ERK phosphorylation in wild-type cerebral cortical explants. Concentrations of the ER- $\beta$-selective ligand genistein, ranging from 0.1 to $100 \mathrm{nM}$, were evaluated for ERK phosphorylation. Genistein failed to elicit ERK phosphorylation at any concentration tested. As a control, we evaluated the efficacy of the compound at a higher $(100 \mu \mathrm{M})$ concentration at which inhibition of tyrosine kinase activity is expected and found that genistein successfully inhibited estradiol-induced ERK phosphorylation to below baseline levels. The bottom panel represents reprobing of the phosphoERK blot for ERK protein to verify equal loading of protein across lanes. Densitometric representation of the relative intensities of ERK1 phosphorylation is also provided, documenting the lack of effect of genistein at the nanomolar concentrations on ERK phosphorylation. Data are representative of two independent experiments.

expression, we studied the effect of $17 \beta$-estradiol on B-Raf activity in both genotypes. In keeping with our earlier observation that cortical B-Raf activity in the rat was strongest in response to a 1 hr exposure of $17 \beta$-estradiol (Singh et al., 1999), we found that a $1 \mathrm{hr}$ treatment with $17 \beta$-estradiol similarly increased B-Raf activity in cerebral cortical explants derived from both wild-type and ERKO mice (Fig. 7).

\section{DISCUSSION}

We have proposed recently a novel and alternative mechanism for estrogen action in the developing brain that involves the activation of multiple signaling intermediates within the MAP kinase cascade through convergence or cross-coupling of the estrogen and neurotrophin signal transduction pathways (Singh et al., 1999). The identification of a second estrogen receptor, ER- $\beta$ (Kuiper et al., 1996; Mosselman et al., 1996; Ogawa et al., 1998), which is expressed with ER- $\alpha$ in explants of the developing cerebral cortex (Toran-Allerand, unpublished observations), raised questions regarding the identity of the estrogen receptor subtype(s) that mediates estrogen activation of ERK. We therefore evaluated the role of ER- $\alpha$ and ER- $\beta$ in estrogen-induced activation of the MAP kinase cascade using both the ER- $\alpha$ gene-disrupted mouse model (ERKO) and pharmacological agonists previously documented to have a selective affinity for either ER- $\alpha$ or ER- $\beta$.

The present study revealed that the disruption of ER- $\alpha$ gene

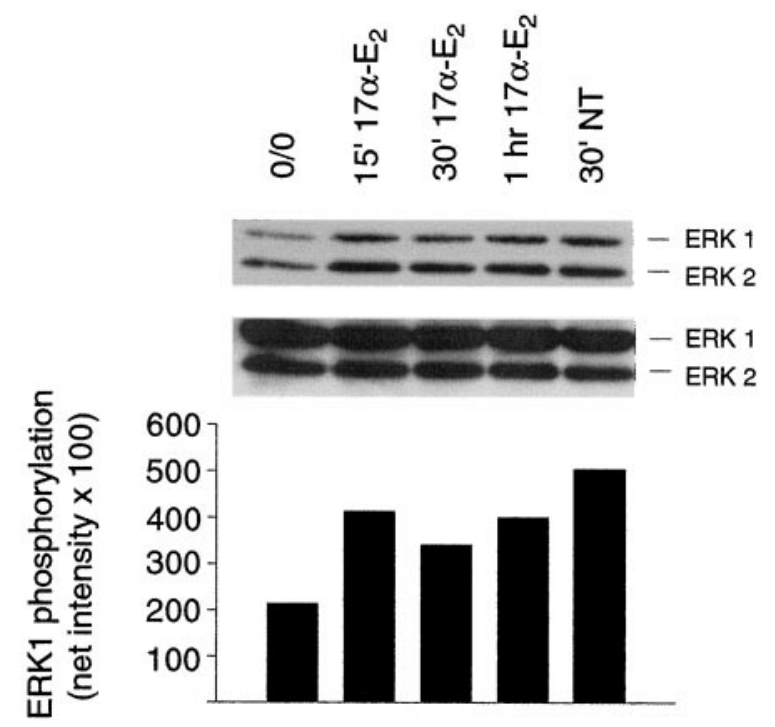

Figure 4. The effect of $17 \alpha$-estradiol on ERK phosphorylation in cerebral cortical cultures. Cultures were treated with $10 \mathrm{~nm} 17 \alpha$-estradiol for 15, 30, and $60 \mathrm{~min}$. At each time point evaluated, $17 \alpha$-estradiol elicited ERK phosphorylation. The bottom panel represents reprobing of the phosphoERK blot for ERK protein to verify equal loading of protein across lanes. Densitometric analysis of the relative intensities of ERK1 phosphorylation is also provided.

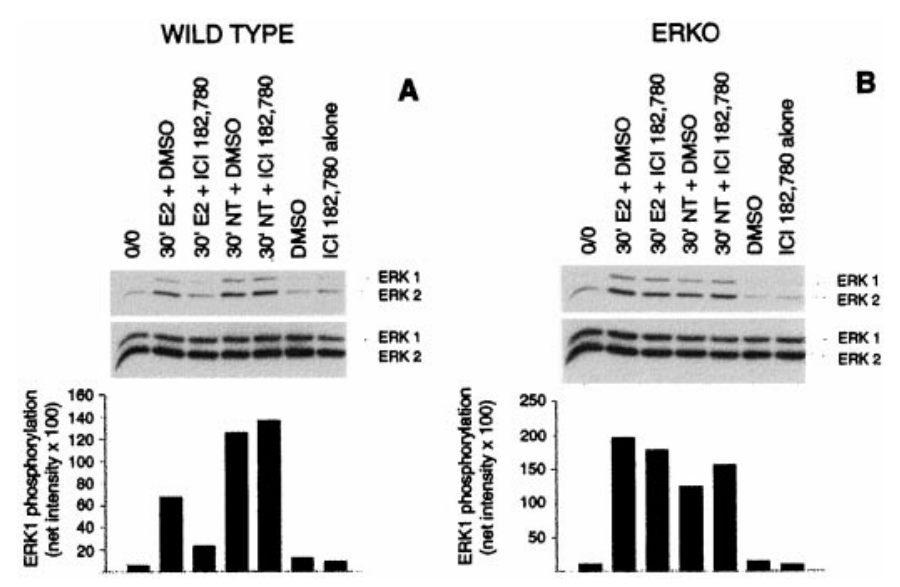

Figure 5. The effect of ICI 182,780 on ERK phosphorylation in wild-type and ERKO cerebral cortex. Cultures were pretreated with either vehicle (DMSO, $0.1 \%$ ) or the ER antagonist ICI 182,780 at a concentration of 1 $\mu \mathrm{M}$ for $24 \mathrm{hr}$ before pulsing. Cultures were pulsed with either $17 \beta$ estradiol (or neurotrophins) in combination with ICI 182,780 or $17 \beta$ estradiol (or neurotrophins) with vehicle. ICI 182,780 successfully inhibited the phosphorylation of ERK only in the wild-type cultures $(A)$, but no effect was observed in ERKO cultures $(B)$. Parallel controls evaluating the effect of either the vehicle $(0.1 \%$ DMSO) or ICI 182,780 alone revealed no contribution to the observed effect of either $17 \beta$-estradiol or the estrogen antagonist. The bottom panels represent reprobing of the phosphoERK blots for ERK protein to verify equal loading of protein across lanes. Densitometric representation of the relative intensities of ERK1 phosphorylation is also provided, revealing the significant inhibition of $17 \beta$-estradiol-induced ERK phosphorylation by ICI 182,870 in wild-type cultures. Data are representative of two independent experiments.

expression in the ERKO cerebral cortex did not prevent $17 \beta$ estradiol from activating members of the MAP kinase cascade, including B-Raf and MEK-dependent ERK phosphorylation. In fact, ERK phosphorylation was significantly stronger in ERKO cortical cultures (Fig. 1). Because the level of ER- $\beta$ mRNA is 
WILD TYPE

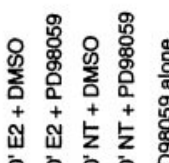

ठ ठ户
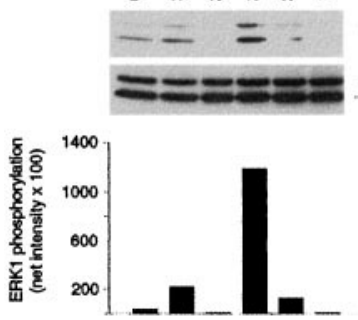

ERKO

A

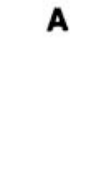

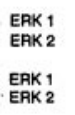

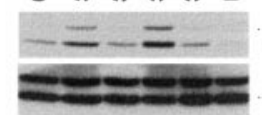

ERK 1
ERK 2
ERK 1
ERK

Figure 6. Effect of PD98059 on ERK phosphorylation in wild-type and ERKO cerebral cortex. The MEK1/2 inhibitor PD98059 was used to evaluate the involvement of the upstream signaling protein MEK in the $17 \beta$-estradiol-induced ERK phosphorylation seen in both wild-type and ERKO cultures. PD98059 $(100 \mu \mathrm{M})$ successfully inhibited both $17 \beta$ estradiol- and neurotrophin-induced ERK phosphorylation in the cultures of both genotypes. The bottom panels represent reprobing of the phosphoERK blot for ERK protein to verify equal loading of protein across lanes. Densitometric representation of the relative intensities of ERK1 phosphorylation is also provided, revealing the significant inhibition of both $17 \beta$-estradiol- and neurotrophin-induced ERK phosphorylation with PD98059 in both wild-type and ERKO cultures. Data are representative of three independent experiments.
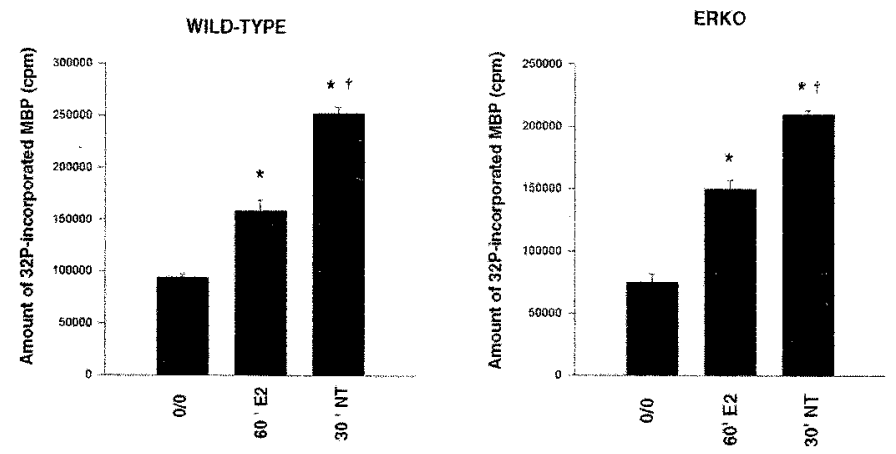

Figure 7. Effect of $17 \beta$-estradiol on B-Raf kinase activity in both wildtype and ERKO cerebral cortex. The amount of ${ }^{32} \mathrm{P}$ incorporated into MBP was evaluated from lysates of cerebral cortical explants immunoprecipitated with the B-Raf antibody. A single $60 \mathrm{~min} 17 \beta$-estradiol treatment significantly increased the kinase activity of B-Raf relative to untreated control in cerebral cortical explants derived from both wildtype and ERKO explants. Treatment of the explants with the neurotrophin cocktail for 30 min served as the positive experimental control and also revealed a significant increase in B-Raf kinase activity. Values represent the average of four samples and were calculated by subtracting the activity level obtained in an IgG-immunoprecipitated control (background) from the values obtained in the experimental samples [ ${ }^{*} p \leq 0.05$ vs untreated control; $\dagger p \leq 0.05$ vs estrogen (E2)].

approximately the same in wild-type as in ERKO animals (Couse et al., 1997) and assuming that the level of translation to functional ER- $\beta$ protein is similar, it is unlikely that the enhanced response to estrogen is caused by a compensatory upregulation of ER- $\beta$. To further evaluate the role of ER- $\alpha$ in the regulation of ERK by estrogen, we analyzed the effect of the ER- $\alpha$-selective ligand $16 \alpha$-iodo- $17 \beta$-estradiol on ERK phosphorylation. At concentrations of $10 \mathrm{nM}$ and below [concentrations that bind preferentially to mouse ER- $\alpha$ (Shughrue et al., 1999)], this ligand failed to elicit the phosphorylation of ERK. In fact, a significant inhi- bition ( $70 \%$ below baseline) was observed, suggesting that ER- $\alpha$ may serve to mediate inhibition of ERK phosphorylation. The enhanced response of ERK to estrogen in ERKO tissue, seen in Figure 1, may also be consistent with this proposed inhibitory role of ER- $\alpha$ in which, in the absence of such inhibitory control, $17 \beta$ estradiol elicits a more robust stimulation of ERK phosphorylation.

We also found that neurotrophin-induced ERK phosphorylation was similarly augmented in the ERKO tissue. Because certain upstream elements of the MAP kinase pathway that are activated by the neurotrophins, such as B-Raf, exist in a multimolecular complex with ER- $\alpha$ (Singh et al., 1999), the disruption of ER- $\alpha$ expression could have consequences for neurotrophin signaling as well. We are currently exploring the mechanisms underlying the enhanced responsiveness of ERK to the neurotrophins in ERKO tissue.

Interestingly, the ER- $\beta$-selective ligand genistein (Witkowska et al., 1997) also failed to elicit ERK phosphorylation, suggesting that ER- $\beta$ may not be involved in this estrogen action either. Because no specific end point that can be ascribed to selective ER- $\beta$ activation is currently known, we were not able to verify whether, in fact, the concentrations of genistein used in our experimental system interact with ER- $\beta$ exclusively. However, in vitro binding studies have demonstrated preferential binding of genistein to the rodent ER- $\beta$ ligand binding domain (Witkowska et al., 1997) at concentrations similar to those used in our study, providing support for its selectivity in our rodent cerebral cortical explant system. In contrast, others (Kuiper et al., 1998) have documented that, in a transient gene expression assay in which both ER- $\alpha$ and ER- $\beta$ were cotransfected with an estrogendependent reporter system, low to mid nanomolar concentrations of genistein could induce transcriptional activity of both ER- $\alpha$ and ER- $\beta$. However, the inability of genistein to elicit ERK phosphorylation despite its apparent ability to activate both ER- $\alpha$ and ER- $\beta$ only further supports our hypothesis that neither of these known receptors are involved in the ability of estradiol to elicit activation of the MAP kinase cascade. Moreover, we found that the estrogen receptor antagonist ICI 182,780, which binds to both ER- $\alpha$ and ER- $\beta$ (Kuiper et al., 1997), did not disrupt $17 \beta-$ estradiol-induced ERK phosphorylation in the ERKO cultures.

We have also observed that $17 \beta$-estradiol, a transcriptionally inactive stereoisomer of $17 \alpha$-estradiol in adult reproductive tissues with 100-fold lower affinity for the estrogen receptor (Ginsburg et al., 1977; Merriam et al., 1980), is equally capable of eliciting robust ERK phosphorylation in wild-type cultures of the cerebral cortex (Fig. 4). 17 $\alpha$-Estradiol, like its stereoisomer, has also been shown to be a potent neuroprotective agent, with only moderate sensitivity to estrogen receptor antagonists (Green et al., 1997) and is postulated to act independently of currently known estrogen receptors (Behl et al., 1997). Thus, it is possible that the ability of $17 \alpha$-estradiol to phosphorylate ERK may occur via a similar alternative pathway, perhaps involving a novel, antagonist-insensitive estrogen receptor. Although these data suggest that a novel estrogen receptor may exist, further analysis in mice lacking the ER- $\beta$ receptor (Krege et al., 1998) will undoubtedly help test this hypothesis.

The existence of novel estrogen receptors has, in fact, been proposed previously. These include the identification of a 112 $\mathrm{kDa}$ estrogen receptor in the adult rat cerebral cortex (Asaithambi et al., 1997) and the characterization of membrane estrogen receptors (estrogen binding sites) in extraneural estrogen targets (Pietras and Szego, 1977; Pappas et al., 1995; Karthikeyan and Thampan, 1996). The latter may either repre- 
sent a subpopulation of the known ER- $\alpha$ or ER- $\beta$ (Pappas et al., 1995; Razandi et al., 1999) or may be a unique, structurally distinct estrogen receptor (Anuradha et al., 1994).

Alternatively, the ability of estradiol to elicit ERK phosphorylation in ERKO tissue could also result from the existence of a functional splice variant of ER- $\alpha$ in the ERKO model (Moffatt et al., 1998). For example, the identification of residual ER- $\alpha$ mRNA and immunoreactivity in ERKO mice was used to support the hypothesis that this residual estrogen receptor could mediate the continued ability of $17 \beta$-estradiol to regulate progesterone receptor expression in specific hypothalamic regions (Moffatt et al., 1998).

Our data describe the ability of ICI 182,780 to inhibit estradiolinduced ERK phosphorylation only in wild-type but not ERKO cerebral cortex. These findings suggest that ER- $\alpha$ may be required to mediate inhibitory modulation of ERK phosphorylation. Support for this hypothesis comes from experiments in which selective activation of ER- $\alpha$ with $16 \alpha$-iodo- $17 \beta$-estradiol resulted in as much as a $70 \%$ inhibition of baseline ERK phosphorylation (Fig. 2). Moreover, the role of ER- $\alpha$ as an inhibitory regulator could explain the enhanced phosphorylation of ERK seen after $17 \beta$-estradiol treatment in the ERKO cerebral cortex (Fig. 1). Thus, after disruption of ER- $\alpha$ expression (ERKO), removal of such inhibitory control would enable estradiol to elicit an unopposed, and hence more robust, stimulation of ERK phosphorylation.

Differences in the responsiveness of wild-type and ERKO tissue to the estrogen receptor antagonist ICI 182,780 are not without precedent. Das et al. (1997), in fact, showed that the effect of the catecholestrogen 4-hydroxy estradiol on uterine lactoferrin expression was not only mediated by a potentially novel estrogen receptor but that ICI 182,780 inhibited this effect in wild-type, but not ERKO, tissue (Das et al., 1997). Additional studies also support the existence of novel, ICI-insensitive estrogen receptors in the rapid and nongenomic actions of estrogens (Das et al., 1997; Gu et al., 1999). For example, 17 $\beta$-estradiolinduced potentiation of kainate-induced currents was not blocked by ICI 182,780 in isolated hippocampal CA1 neurons of both wild-type and ERKO mice (Gu et al., 1999).

Because the data described here argue against a direct role for ER- $\alpha$ in the mediation of estrogen-induced ERK phosphorylation, ER- $\alpha$ must modulate the inhibition of ERK phosphorylation by influencing the estrogen receptor specifically responsible for the induction. Such an influence of one receptor over another could be achieved through an interaction (heterodimerization) between ER- $\alpha$ and other receptor subtypes. Heterodimerization of estrogen receptor isoforms (ER- $\alpha$ and ER- $\beta$ ) has, in fact, been demonstrated (Pace et al., 1997; Pettersson et al., 1997; Ogawa et al., 1998). We propose that inhibitory modulation of estrogeninduced ERK phosphorylation may occur through heterodimerization of ER- $\alpha$ with a novel, ICI-insensitive estrogen receptor. However, after disruption of ER- $\alpha$ expression (as in ERKO), no ER- $\alpha$-containing heterodimers would exist, and this mediator of inhibitory regulation would be absent. As a result, ICI 182,780 would become incapable of influencing estradiol-induced phosphorylation of ERK in ERKO cerebral cortex, a hypothesis consistent with our findings.

Convergence of estrogen- and growth factor-signaling pathways in the brain provides a novel mechanism that may explain how estrogen and the neurotrophins can each regulate the same growth- and neurite-related genes, such as $\beta$-tubulin (Guo and Gorski, 1988), MAP2 (Black et al., 1986; Lorenzo et al., 1992), tau microtubule-associated protein (Drubin et al., 1985; Ferreira and Caceres, 1991), and growth-associated protein 43 (Federoff et al., 1988; Lustig et al., 1991). Estrogen activation of the MAP kinase cascade may also be particularly relevant for cognition and its associated disorders, including such neurodegenerative diseases as Alzheimer's disease (AD). Both estrogen exposure (Jaffe et al., 1994; Xu et al., 1998) and activation of the MAP kinase cascade (Mills et al., 1997; Desdouits-Magnen et al., 1998) have been shown to reduce the potential of forming $\beta$-amyloid, a protein of considerable focus in the pathophysiology of AD (Selkoe, 1994), by upregulating $\alpha$-secretase activity. Thus, estrogen activation of the MAP kinase cascade may be very important not only for neuronal differentiation but may also explain how, through regulation of amyloid metabolism, estrogen could exert some of its known neuroprotective effects in neurodegenerative disorders such as AD (Fillit et al., 1986; Paganini-Hill and Henderson, 1994; Tang et al., 1996; Simpkins et al., 1997).

\section{REFERENCES}

Akiyama T, Ishida J, Nakagawa S, Ogawara H, Watanabe S, Itoh N, Shibuya M, Fukami Y (1987) Genistein, a specific inhibitor of tyrosine-specific protein kinases. J Biol Chem 262:5592-5595.

Anuradha P, Khan SM, Karthikeyan N, Thampan RV (1994) The nonactivated estrogen receptor (naER) of the goat uterus is a tyrosine kinase. Arch Biochem Biophys 309:195-204.

Asaithambi A, Mukherjee S, Thakur MK (1997) Expression of 112-kDa estrogen receptor in mouse brain cortex and its autoregulation with age. Biochem Biophys Res Commun 231:683-685.

Behl C, Widmann M, Trapp T, Holsboer F (1995) 17-Beta estradiol protects neurons from oxidative stress-induced cell death in vitro. Biochem Biophys Res Commun 216:473-482.

Behl C, Skutella T, Lezoualc'h F, Post A, Widmann M, Newton CJ, Holsboer F (1997) Neuroprotection against oxidative stress by estrogens: structure- activity relationship. Mol Pharmacol 51:535-541.

Black M, Aletta J, Greene L (1986) Regulation of microtubule composition and stability during nerve growth factor-promoted neurite outgrowth. J Cell Biol 103:545-557.

Chiaia N, Foy M, Teyler TJ (1983) The hamster hippocampal slice. II. Neuroendocrine modulation. Behav Neurosci 97:839-843.

Couse JF, Lindzey J, Grandien K, Gustafsson JA, Korach KS (1997) Tissue distribution and quantitative analysis of estrogen receptor- alpha (ERalpha) and estrogen receptor-beta (ERbeta) messenger ribonucleic acid in the wild-type and ERalpha-knockout mouse. Endocrinology 138:4613-4621.

Das SK, Taylor JA, Korach KS, Paria BC, Dey SK, Lubahn DB (1997) Estrogenic responses in estrogen receptor-alpha deficient mice reveal a distinct estrogen signaling pathway. Proc Natl Acad Sci USA 94:12786-12791.

Desdouits-Magnen J, Desdouits F, Takeda S, Syu LJ, Saltiel AR, Buxbaum JD, Czernik AJ, Nairn AC, Greengard P (1998) Regulation of secretion of Alzheimer amyloid precursor protein by the mitogenactivated protein kinase cascade. J Neurochem 70:524-530.

Drubin D, Feinstein S, Shooter E, Kirschner M (1985) Nerve growth factor-induced neurite outgrowth in PC12 cells involves the coordinate induction of microtubule assembly and assembly-promoting factors. J Cell Biol 101:1799-1807.

Federoff HJ, Grabczyk E, Fishman MC (1988) Dual regulation of GAP-43 gene expression by nerve growth factor and glucocorticoids. J Biol Chem 263:19290-19295.

Ferreira A, Caceres A (1991) Estrogen-enhanced neurite growth: evidence for a selective induction of tau and stable microtubules. J Neurosci 11:392-400.

Fillit H, Weinreb H, Cholst I, Luine V, McEwen B, Amador R, Zabriskie J (1986) Observations in a preliminary open trial of estradiol therapy for senile dementia-Alzheimer's type. Psychoneuroendocrinology 11:337-345.

Garcia-Segura LM, Olmos G, Tranque P, Naftolin F (1987) Rapid effects of gonadal steroids upon hypothalamic neuronal membrane ultrastructure. J Steroid Biochem 27:615-623.

Ginsburg M, MacLusky NJ, Morris ID, Thomas PJ (1977) The specificity of oestrogen receptor in brain, pituitary and uterus. $\mathrm{Br} \mathrm{J}$ Pharmacol 59:397-402. 
Green PS, Gridley KE, Simpkins JW (1996) Estradiol protects against beta-amyloid (25-35)-induced toxicity in SK-N-SH human neuroblastoma cells. Neurosci Lett 218:165-168.

Green PS, Bishop J, Simpkins JW (1997) 17 alpha-estradiol exerts neuroprotective effects on SK-N-SH cells. J Neurosci 17:511-515.

Gu Q, Korach KS, Moss RL (1999) Rapid action of 17beta-estradiol on kainate-induced currents in hippocampal neurons lacking intracellular estrogen receptors. Endocrinology 140:660-666.

Guo JZ, Gorski J (1988) Estrogen effects on histone messenger ribonucleic acid levels in the rat uterus. Mol Endocrinol 2:693-700.

Hochberg RB, Rosner W (1980) Interaction of 16 alpha- $\left[{ }^{125}\right.$ I]iodoestradiol with estrogen receptor and other steroid-binding proteins. Proc Natl Acad Sci USA 77:328-332.

Jaffe A, Toran-Allerand CD, Greengard P, Gandy S (1994) Estrogen regulates metabolism of Alzheimer amyloid beta precursor protein. J Biol Chem 269:13065-13068.

Karthikeyan N, Thampan RV (1996) Plasma membrane is the primary site of localization of the nonactivated estrogen receptor in the goat uterus: hormone binding causes receptor internalization. Arch Biochem Biophys 325:47-57.

Krege JH, Hodgin JB, Couse JF, Enmark E, Warner M, Mahler JF, Sar M, Korach KS, Gustafsson JA, Smithies O (1998) Generation and reproductive phenotypes of mice lacking estrogen receptor beta. Proc Natl Acad Sci USA 95:15677-15682.

Kuiper GG, Enmark E, Pelto-Huikko M, Nilsson S, Gustafsson JA (1996) Cloning of a novel receptor expressed in rat prostate and ovary. Proc Natl Acad Sci USA 93:5925-5930.

Kuiper GG, Carlsson B, Grandien K, Enmark E, Haggblad J, Nilsson S, Gustafsson JA (1997) Comparison of the ligand binding specificity and transcript tissue distribution of estrogen receptors alpha and beta. Endocrinology 138:863-870.

Kuiper GG, Lemmen JG, Carlsson B, Corton JC, Safe SH, van der Saag PT, van der Burg B, Gustafsson JA (1998) Interaction of estrogenic chemicals and phytoestrogens with estrogen receptor beta. Endocrinology 139:4252-4263.

Lorenzo A, Diaz H, Carrer H, Caceres A (1992) Amygdala neurons in vitro: neurite growth and effects of estradiol. J Neurosci Res 33:418-435.

Lubahn DB, Moyer JS, Golding TS, Couse JF, Korach KS, Smithies O (1993) Alteration of reproductive function but not prenatal sexual development after insertional disruption of the mouse estrogen receptor gene. Proc Natl Acad Sci USA 90:11162-11166.

Luine VN, Richards ST, Wu VY, Beck KD (1998) Estradiol enhances learning and memory in a spatial memory task and effects levels of monoaminergic neurotransmitters. Horm Behav 34:149-162.

Lustig R, Sudol M, Pfaff D, Federoff H (1991) Estrogenic regulation and sex dimorphism of growth-associated protein $43 \mathrm{kDa}$ (GAP-43) messenger RNA in the rat. Brain Res Mol Brain Res 11:125-132.

Merriam GR, MacLusky NJ, Johnson LA, Naftolin F (1980) 2-hydroxyestradiol-17 alpha and 4-hydroxyestradiol-17 alpha, catechol estrogen analogs with reduced estrogen receptor affinity. Steroids 36:13-20.

Migliaccio A, Pagano M, Auricchio F (1993) Immediate and transient stimulation of protein tyrosine phosphorylation by estradiol in MCF-7 cells. Oncogene 8:2183-2191.

Mills J, Laurent Charest D, Lam F, Beyreuther K, Ida N, Pelech SL, Reiner PB (1997) Regulation of amyloid precursor protein catabolism involves the mitogen-activated protein kinase signal transduction pathway. J Neurosci 17:9415-9422.

Miranda R, Sohrabji F, Toran-Allerand CD (1993) Neuronal colocalization of mRNAs for neurotrophins and their receptors in the developing central nervous system suggests a potential for autocrine interactions. Proc Natl Acad Sci USA 90:6439-6443.

Moffatt CA, Rissman EF, Shupnik MA, Blaustein JD (1998) Induction of progestin receptors by estradiol in the forebrain of estrogen receptoralpha gene-disrupted mice. J Neurosci 18:9556-9563.

Mosselman S, Polman J, Dijkema R (1996) ER beta: identification and characterization of a novel human estrogen receptor. FEBS Lett 392:49-53.

Ogawa S, Inoue S, Watanabe T, Hiroi H, Orimo A, Hosoi T, Ouchi Y, Muramatsu M (1998) The complete primary structure of human estrogen receptor beta (hER beta) and its heterodimerization with ER alpha in vivo and in vitro. Biochem Biophys Res Commun 243:122-126.
Pace P, Taylor J, Suntharalingam S, Coombes RC, Ali S (1997) Human estrogen receptor beta binds DNA in a manner similar to and dimerizes with estrogen receptor alpha. J Biol Chem 272:25832-25838.

Paganini-Hill A, Henderson VW (1994) Estrogen deficiency and risk of Alzheimer's disease in women. Am J Epidemiol 140:256-261.

Pappas TC, Gametchu B, Watson CS (1995) Membrane estrogen receptors identified by multiple antibody labeling and impeded-ligand binding. FASEB J 9:404-410.

Pettersson K, Grandien K, Kuiper GG, Gustafsson JA (1997) Mouse estrogen receptor beta forms estrogen response element-binding heterodimers with estrogen receptor alpha. Mol Endocrinol 11:1486-1496.

Pietras RJ, Szego CM (1977) Specific binding sites for oestrogen at the outer surfaces of isolated endometrial cells. Nature 265:69-72.

Razandi M, Pedram A, Greene GL, Levin ER (1999) Cell membrane and nuclear estrogen receptors (ERs) originate from a single transcript: studies of ERalpha and ERbeta expressed in Chinese hamster ovary cells. Mol Endocrinol 13:307-319.

Selkoe DJ (1994) Normal and abnormal biology of the beta-amyloid precursor protein. Annu Rev Neurosci 17:489-517.

Shughrue PJ, Lane MV, Merchenthaler I (1999) Biologically active estrogen receptor-beta: evidence from in vivo autoradiographic studies with estrogen receptor alpha-knockout mice. Endocrinology 140:2613-2620.

Simpkins JW, Green PS, Gridley KE, Singh M, de Fiebre NC, Rajakumar G (1997) Role of estrogen replacement therapy in memory enhancement and the prevention of neuronal loss associated with Alzheimer's disease. Am J Med 103:19S-25S.

Singh M, Meyer EM, Millard WJ, Simpkins JW (1994) Ovarian steroid deprivation results in a reversible learning impairment and compromised cholinergic function in female Sprague-Dawley rats. Brain Res 644:305-312.

Singh M, Sétáló Jr G, Guan X, Warren M, Toran-Allerand CD (1999) Estrogen-induced activation of mitogen-activated protein kinase in cerebral cortical explants: convergence of estrogen and neurotrophin signaling pathways. J Neurosci 19:1179-1188.

Sohrabji F, Greene L, Miranda R, Toran-Allerand CD (1994) Reciprocal regulation of estrogen and NGF receptors by their ligands in PC12 cells. J Neurobiol 25:974-988.

Sukovich DA, Mukherjee R, Benfield PA (1994) A novel, cell-typespecific mechanism for estrogen receptor-mediated gene activation in the absence of an estrogen-responsive element. Mol Cell Biol 14:7134-7143.

Tang MX, Jacobs D, Stern Y, Marder K, Schofield P, Gurland B, Andrews H, Mayeux R (1996) Effect of oestrogen during menopause on risk and age at onset of Alzheimer's disease. Lancet 348:429-432.

Toran-Allerand CD (1976) Sex steroids and the development of the newborn mouse hypothalamus and preoptic area in vitro: implications for sexual differentiation. Brain Res 106:407-412.

Toran-Allerand CD (1984) On the genesis of sexual differentiation of the central nervous system: morphogenetic consequences of steroidal exposure and possible role of alpha-fetoprotein. Prog Brain Res 61:63-98.

Toran-Allerand CD (1996) The estrogen/neurotrophin connection during neural development: is co-localization of estrogen receptors with the neurotrophins and their receptors biologically relevant? Dev Neurosci 18:36-48.

Toran-Allerand CD, Miranda R, Bentham W, Sohrabji F, Brown T, Hochberg R, MacLusky N (1992) Estrogen receptors colocalize with low-affinity nerve growth factor receptors in cholinergic neurons of the basal forebrain. Proc Natl Acad Sci USA 89:4668-4672.

Witkowska HE, Carlquist M, Engstrom O, Carlsson B, Bonn T, Gustafsson JA, Shackleton CH (1997) Characterization of bacterially expressed rat estrogen receptor beta ligand binding domain by mass spectrometry: structural comparison with estrogen receptor alpha. Steroids $62: 621-631$.

$\mathrm{Xu} \mathrm{H}$, Gouras GK, Greenfield JP, Vincent B, Naslund J, Mazzarelli L, Fried G, Jovanovic JN, Seeger M, Relkin NR, Liao F, Checler F, Buxbaum JD, Chait BT, Thinakaran G, Sisodia SS, Wang R, Greengard P, Gandy S (1998) Estrogen reduces neuronal generation of Alzheimer beta-amyloid peptides. Nat Med 4:447-451.

Zhou X, Rush R (1995) Sympathetic neurons in neonatal rats require endogenous neurotrophin-3 for survival. J Neurosci 15:6521-6530. 